\title{
PIRANTI LUNAK PENGUJIAN STRUKTUR MATEMATIKA GRUP, RING, FIELD BERBASIS OSP (Open Source Program)
}

\author{
Ngarap Im Manik; Don Tasman \\ Mathematics and Statistics Department, School of Computer Science, Binus University \\ Jln. K.H. Syahdan No. 9 Palmerah, Jakarta Barat 11480 \\ manik@binus.edu
}

\begin{abstract}
This design of a computer software is a development and continuation of the software made on the previous research (2009/2010). However, this further research developed and expanded the scopes of testing more on the Siclic Group, Isomorphism Group, Semi Group, Sub Group and Abelian Group, Factor Ring, Sub Ring and Polynomial Ring; developed on the OSP (Open Source Program)-based. The software was developed using the OSP-based language programming, such Java, so it is open and free to use for its users. This research succeeded to develop an open source software of Java program that can be used for testing specific mathematical Groups, such Ciclic Group, Isomorphism Group, Semi Group, Sub Group and Abelian Group, and Rings, Commutative Ring, Division Ring, Ideal Sub Ring, Ring Homomorphism, Ring Epimorphism and Fields. By the results, the software developed was able to test as same as the results from manual testing.
\end{abstract}

Keywords: mathematic structures, groups, rings, fields, open source program

\begin{abstract}
ABSTRAK
Piranti lunak komputer yang dirancang ini adalah pengembangan dan kelanjutan dari sebuah piranti lunak komputer yang sudah dibuat pada penelitian sebelumnya (2009/2010). Namun pada penelitian lanjutan ini lebih dikembangkan dan diperluas cakupan bahasan pengujiannya seperti Grup Siklik, Grup Isomorphisma, Semi Grup, Sub Grup dan Grup Abelian, Ring Faktor, Sub Ring dan Ring Polinom yang dikembangkan berbasis OSP (Open Source Program). Piranti lunak ini dikembangkan dengan menggunakan bahasa pemrograman berbasis OSP seperti Java dan piranti lunak dimaksud dapat digunakan secara terbuka dan gratis bagi para penggunanya. Hasil penelitian ini telah berhasil dikembangkan sebuah perangkat lunak berbasis open source program Java yang dapat digunakan untuk pengujian struktur matematika Grup khusus seperti Grup Siklik, Grup Isomorphisma, Semi Grup, Sub Grup dan Grup Abelian, dan Ring, Comutative Ring, Divisoin Ring, Sub Ring Ideal, Homomorphisma Ring, Epimorphisma Ring, Isomorphisma Ring dan Field. Dari hasil yang diperoleh menunjukkan bahwa piranti lunak yang dikembangkan dapat menguji sesuai dengan hasil bila pengujian dilakukan secara manual.
\end{abstract}

Kata kunci: Struktur matematika, grup, ring, field, open source program 


\section{PENDAHULUAN}

Berbicara tentang Struktur Matematika, ada tiga hal yang tercakup di dalamnya yaitu ring, field dan Grup. Ring, field \& Grup merupakan bagian dari kelompok matematika struktur aljabar/group yang umumnya digunakan untuk membuktikan suatu himpunan apakah memenuhi operator biner dan himpunan tidak kosong $\mathrm{R}$ terhadap dua operasi + dan *. Kedua metode ini merupakan metode pembuktian dengan menggunakan definisi, teorema, dalil dan axioma. Seperti yang telah disebutkan sebelumnya, salah satu yang dipelajari dalam ilmu Struktur Matematika adalah teori grup. Ide dasar munculnya teori grup adalah penyelidikan permutasi dari himpunan berhingga di dalam teori persamaan (Daniel, 2011; Bergstra \& Tucker, 2008).

Ruang lingkup pembuatan piranti lunak aplikasi ini dibatasi untuk pengujian Grup, Ring, dan Field. Program aplikasi ini akan melakukan uji dengan mengecek persyaratan yang ada dengan menggunakan tabel Cayley serta rumusan-rumusan yang berlaku dan pembuatan program aplikasi ini menggunakan bahasa pemrograman Open source Java. Piranti lunak ini dikembangkan dengan menggunakan bahasa pemrograman Java. Hal lain yang ingin dicapai bahwa dengan adanya piranti lunak komputer ini, nantinya dapat membantu para guru dan siswa SMA serta mahasiswa untuk lebih meminati bidang ilmu matematika dan juga untuk antisipasi penggunaan paket piranti yang telah ada (Mapple, Matlab) yang bila digunakan harus memiliki lisensi program tersebut.

Beberapa topik penelitian telah dilakukan sebelumnya yaitu oleh Stefaan Caenepeel \& Alain Verschoren, 2009 tentang "Noncommutative Rings and Geometry" yang membahas non kumutatif ring melalui sebuah grup, serta D.A.R. Wallace, 2004 melakukan pembuktian struktur aljabar ring dengan memanfaatkan teorema group.

Demikian juga Muzaffer Okur et al, 2011 telah mengembangkan model GAP (Group, Algorithm, Programming) utk melakukan pembuktian sebuah group dan subgroup. Demikian pula dengan Ngarap Im Manik dkk, 2010 telah melakukan perancangan piranti lunak untuk pembuktian grup khusus (Grup, SubGrup dan Homomorphisma grup) dengan menggunakan alat bantu piranti lunak komputer. Demikian juga oleh Suryoto dan Iswati, 2008 K-Aljabar. Penelitian ini membahas mengenai struktur aljabar yang dibangun atas suatu grup sehingga sifat-sifat yang berlaku pada grup akan berlaku juga pada K-Aljabar. Jika grup terdapat subgrup dan homomorfisma grup, maka pada KAljabar terdapat K-Sub aljabar dan K-Homomorfisma. Nancy, S., 2009 melakukan penelitian Program Aplikasi Pengujian Grup. Dalam penelitian ini, program aplikasi hanya mencakup pembuktian struktur aljabar umum hingga grup abelian (komutatif). Selain itu, program tersebut hanya mendukung pengujian untuk sebuah sistem aljabar. Andrew Saputra, 2010, meneliti Perancangan Program Aplikasi Pengujian Struktur Aljabar Grup Khusus (Abelian, Siklik, Homomorfisma, Isomorfisma, Monomorfisma, dan Epimorfisma). Dalam makalah ini, piranti lunak yang dirancang mempunyai kemampuan untuk menguji bentuk-bentuk grup khusus meliputi grup siklik, grup homomorfis, isomorfis, monomorfis, dan epimorfis. Selain itu juga dapat menguji tentang pengujian struktur aljabar ring, pembagian ring (sub ring, ring komutatif, division ring, homomorfisma ring, epimorfisma ring, ring embeddings/monomorfisma ring, isomorfisma ring), dan field, sehingga dapat mempermudah, mempercepat, serta meningkatkan ketelitian pengujian struktur aljabar.

\section{Grup}

Grup adalah suatu sistem atau struktur aljabar yang sederhana. Jika suatu himpunan $G \neq \varnothing$ dengan suatu operasi ${ }^{\circ}$ yang didefinisikan bagi elemen-elemen $G$ bersifat tertutup, asosiatif, mempunyai elemen identitas dan setiap elemen $G$ mempunyai invers terhadap operasi biner tersebut, maka himpunan $G$ terhadap operasi biner itu membentuk suatu grup. Selanjutnya keempat sifat tersebut dinamakan aksioma-aksioma suatu grup (Weisstein, et al. 2009). Suatu himpunan G yang 
tidak kosong dan suatu operasi biner $\circ$ yang didefinisikan pada $G$ membentuk suatu grup bila dan hanya bila memenuhi sifat-sifat berikut ini: (1) Tertutup, $\forall a, b \in G$ berlaku ( $\left.a^{\circ} b\right) \in G$. (2) Operasi $\circ$ pada $G$ bersifat asosiatif, yaitu untuk setiap $a, b, c, \in G$ maka $(a \circ b) \circ c=a \circ(b \circ c)$. (3) $G$ terhadap operasi biner $\circ$ mempunyai elemen identitas, yaitu ada $e \in G$ sehingga $a \circ e=e \circ a=a$ untk setiap $a \in G$. (4) Setiap elemen $G$ mempunyai invers terhadap operasi biner $\circ$ dalam $G$, yaitu untuk setiap $\mathrm{a} \in \mathrm{G}$ ada $\mathrm{a}^{-1} \in \mathrm{G}$ sedemikian hingga $\mathrm{a} \circ \mathrm{a}^{-1}=\mathrm{a}^{-1} \circ \mathrm{a}=\mathrm{e}$ adalah elemen identitas dari $\mathrm{G}$.

Jika himpunan $G$ terhadap operasi biner o membentuk suatu grup, maka grup $G$ ini dinyatakan dengan notasi (G,o) (Manik, N.I, 2010; Malik, D.S., et al., 2007). Tidak setiap grup memiliki sifat komutatif terhadap binernya. Operasi biner $\circ$ pada $G$ bersifat komutatif yaitu untuk setiap $a, b \in G$ maka $a \circ b=b \circ a$. Shg grup $(G, \circ)$ disebut grup abelian atau grup komutatif (Dewi, N.R., et al., 2011).

\section{Ring}

Ring adalah suatu struktur aljabar yang terdiri dari dua operasi biner yaitu penjumlahan dan perkalian, di mana terhadap penjumlahan struktur tersebut merupakan grup abelian, terhadap perkalian struktur tersebut merupakan semigrup dan operasi perkalian bersifat distributif terhadap operasi penjumlahan. Suatu ring $(\mathrm{R},+, \times)$ adalah suatu himpunan tak kosong $\mathrm{R}$ dengan operasi biner penjumlahan $(+)$ dan perkalian $(\times)$ pada $\mathrm{R}$ yang memenuhi aksioma-aksioma berikut.

Terhadap penjumlahan $(+)$

Tertutup: Untuk setiap a,b $\varepsilon$ R, maka $a+b \quad \varepsilon$ R.

Asosiatif: Untuk setiap a,b,c $\varepsilon$ R, maka $(a+b)+c=a+(b+c)$.

Mempunyai unsur kesatuan: Adanya elemen identitas $\alpha$ sehingga $a+\alpha=\alpha+a=a$.

Mempunyai invers: Untuk setiap a $\varepsilon R$ terdapat $b$ sedemikian hingga $a+b=b+a=\alpha$.

Komutatif: Untuk setiap $a, b \varepsilon R$, maka $a+b=b+a$.

Terhadap perkalian $(\times)$

Tertutup: Untuk setiap a,b $\varepsilon$ R, maka $a \times b \quad \varepsilon$ R.

Asosiatif: Untuk setiap a,b,c $\varepsilon R$, maka $(a \times b) \times c=a \times(b \times c)$.

Distributif perkalian $(\times)$ terhadap penjumlahan $(+)$; Untuk setiap a,b,c $\varepsilon$ R, jika memenuhi:

Distributif Kiri : Untuk setiap a,b,c $\varepsilon$ R memenuhi $a \times(b+c)=(a \times b)+(a \times c)$

Distributif Kanan: Untuk setiap a,b,c $\varepsilon R$ memenuhi $(\mathrm{a}+\mathrm{b}) \times \mathrm{c}=(\mathrm{a} \times \mathrm{c})+(\mathrm{b} \times \mathrm{c})$ maka $\mathrm{R}$ bersifat distributif perkalian terhadap penjumlahan (Gilbert \& Nicholson, 2004)

\section{Ring Komutatif}

Ring komutatif atau gelanggang komutatif adalah suatu ring, di mana terhadap penjumlahan struktur tersebut merupakan grup abelian, terhadap perkalian struktur tersebut merupakan semigrup komutatif dan operasi perkalian bersifat distributif terhadap operasi penjumlahan. Suatu ring komutatif $(\mathrm{R},+, \times)$ adalah suatu himpunan tak kosong $\mathrm{R}$ dengan operasi biner penjumlahan $(+)$ dan perkalian $(\times)$ pada $\mathrm{R}$ yang memenuhi aksioma-aksioma berikut.

Terhadap penjumlahan $(+)$

Tertutup: Untuk setiap a,b. $\varepsilon \mathrm{R}$, maka a + b $\varepsilon \mathrm{R}$. 
Asosiatif: Untuk setiap a,b,c $\varepsilon$ R, maka $(a+b)+c=a+(b+c)$.

Mempunyai unsur kesatuan: Adanya elemen identitas $\alpha$ sehingga $a+\alpha=\alpha+a=a$.

Mempunyai invers: Untuk setiap a $\varepsilon R$ terdapat $b$ sedemikian hingga $a+b=b+a=\alpha$.

Komutatif: Untuk setiap $a, b \in R$, maka $a+b=b+a$.

Terhadap perkalian $(\times)$

Tertutup: Untuk setiap a,b $\varepsilon \mathrm{R}$, maka a $\times$ b $\varepsilon$ R.

Asosiatif: Untuk setiap a,b,c $\varepsilon$ R, maka $(a \times b) \times c=a \times(b \times c)$.

Mempunyai unsur kesatuan: Adanya elemen identitas $\beta$ sehingga $a \times \beta=\beta \times a=a$.

Komutatif: Untuk setiap a,b $\varepsilon$ R, maka $a \times b=b \times a$.

Distributif perkalian $(\times)$ terhadap penjumlahan $(+)$

Untuk setiap a,b,c $\varepsilon$ R, jika memenuhi:

Distributif Kiri: Untuk setiap a,b,c $\varepsilon$ R memenuhi $a \times(b+c)=(a \times b)+(a \times c)$

Distributif Kanan: Untuk setiap a,b,c $\varepsilon$ R memenuhi $(\mathrm{a}+\mathrm{b}) \times \mathrm{c}=(\mathrm{a} \times \mathrm{c})+(\mathrm{b} \times \mathrm{c})$ maka $\mathrm{R}$ bersifat distributif perkalian terhadap penjumlahan (Gilbert \& Nicholson, 2004).

\section{Field}

Field adalah suatu struktur aljabar yang terdiri dari dua operasi biner yaitu penjumlahan dan perkalian, di mana himpunan terhadap penjumlahan, struktur tersebut merupakan grup abelian, himpunan tanpa nol dengan operasi perkalian merupakan grup abelian, dan operasi perkalian bersifat distributif terhadap operasi penjumlahan. Suatu field $(\mathrm{R},+, \times)$ adalah suatu himpunan tak kosong $\mathrm{R}$ dengan operasi biner penjumlahan $(+)$ dan perkalian $(\times)$ pada $R$ yang memenuhi aksioma-aksioma berikut.

R terhadap penjumlahan $(+)$

Tertutup: Untuk setiap a,b $\varepsilon$ R, maka a + b $\varepsilon$ R.

Asosiatif: Untuk setiap a,b,c $\varepsilon R$, maka $(a+b)+c=a+(b+c)$.

Mempunyai unsur kesatuan: Adanya elemen identitas $\alpha$ sehingga $a+\alpha=\alpha+a=a$.

Mempunyai invers: Untuk setiap a $\varepsilon R$ terdapat $b$ sedemikian hingga $a+b=b+a=\alpha$.

Komutatif: Untuk setiap a,b $\varepsilon R$, maka $a+b=b+a$.

$\mathrm{R}$ tanpa nol terhadap perkalian $(\times)$

Tertutup: Untuk setiap a,b $\varepsilon \mathrm{R}$, maka a $\times$ b $\varepsilon \mathrm{R}$.

Asosiatif: Untuk setiap a,b,c $\varepsilon$ R, maka $(a \times b) \times c=a \times(b \times c)$.

Mempunyai unsur kesatuan: Adanya elemen identitas $\beta$ sehingga $a \times \beta=\beta \times a=a$.

Mempunyai invers: Untuk setiap a $\varepsilon \mathrm{R}-\{0\}$ terdapat $\mathrm{b}$ sehingga $\mathrm{a} \times \mathrm{b}=\mathrm{b} \times \mathrm{a}=\beta$.

Komutatif: Untuk setiap $a, b \varepsilon \varepsilon$, maka $a \times b=b \times a$.

Distributif perkalian $(\times)$ terhadap penjumlahan $(+)$ Untuk setiap a,b,c $\varepsilon$ R, jika memenuhi:

Distributif Kiri: Untuk setiap a,b,c $\varepsilon$ R memenuhi $a \times(b+c)=(a \times b)+(a \times c)$

Distributif Kanan: Untuk setiap a,b,c $\varepsilon R$ memenuhi $(\mathrm{a}+\mathrm{b}) \times \mathrm{c}=(\mathrm{a} \times \mathrm{c})+(\mathrm{b} \times \mathrm{c})$ maka $\mathrm{R}$ bersifat distributif perkalian terhadap penjumlahan. 


\section{Sub Ring}

Misalkan $(\mathrm{R},+, \times)$ adalah suatu ring, A adalah merupakan himpunan tidak kosong yang merupakan bagian dari $\mathrm{R}(\mathrm{A} \subseteq \mathrm{R})$. Di bawah operasi yang sama dengan $\mathrm{R},(\mathrm{A},+, \times)$ membentuk suatu ring, himpunan A disebut sub ring dari himpunan $\mathrm{R}$ (Weisstein, et al. 2009).

\section{Sub Ring Ideal}

Ideal adalah sub ring yang memiliki sifat istimewa yaitu tertutup terhadap perkalian unsur di luar sub ring. Suatu sub ring disebut ideal jika sub ring tersebut merupakan ideal kiri (tertutup terhadap perkalian unsur di sebelah kiri) dan ideal kanan (tertutup terhadap perkalian unsur di sebelah kanan) (Okur, 2006).

\section{Ring Pembagian (Division Ring)}

Ring pembagian adalah suatu ring, di mana elemen-elemen tak nol-nya membentuk grup di bawah operasi x (Pevtsova, et al., 2009).

\section{METODE}

Untuk dapat melakukan pengujian struktur matematika grup dilakukan dengan merancang sebuah perangkat lunak komputer berbasis open source., yang secara umum meliputi kegiatan atau tahapan analysist - design - coding (construction) - testing - maintenance.

Sistem dibuat dan dirancang sedemikian rupa agar menghasilkan sebuah aplikasi program yang efisien dan mudah digunakan oleh pengguna serta dapat memberikan hasil keluaran yang jelas dan mudah dipahami pengguna program aplikasi tersebut (Carlson, 2003). Langkah awal yang dilakukan sebelum membuat perangkat lunak adalah merancangnya terlebih dahulu. Perancangan perangkat lunak adalah disiplin manajerial dan teknis yang berkaitan dengan pembuatan dan pemeliharaan produk perangkat lunak secara sistematis, termasuk pengembangan dan modifikasinya, yang dilakukan pada waktu yang tepat dan dengan pertimbangan faktor biaya.

Langkah pertama yang perlu dilakukan oleh pengguna adalah memasukkan data dan elemen sistem aljabar yang dibutuhkan untuk proses pengujian sifat. Pengguna akan memasukkan data dan elemen pada himpunan yang akan diuji. Pengguna dapat memasukkan data untuk satu atau dua buah himpunan sesuai kebutuhan. Jika pengguna ingin menguji sampai sifat grup faktor, homomorfisma, dan subgrup normal, maka pengguna perlu memasukkan data elemen untuk kedua himpunan. Selain itu pengguna juga perlu memasukkan hasil operasi untuk tiap pasang elemen himpunan tersebut ke dalam tabel Cayley yang akan di-generate oleh program. Setelah data elemen dan hasil operasi dari tiap sistem aljabar selesai dimasukkan pengguna, secara otomatis program melakukan pengolahan data.

Hasil dari proses pengolahan data ini adalah berupa sifat-sifat umum dari operasi aljabar yang telah teruji, mulai dari sifat tertutup, asosiatif, ada tidaknya elemen identitas, ada tidaknya invers bagi setiap elemen dalam sistem aljabar, serta sifat komutatif. Selanjutnya, program akan melakukan pengujian untuk klasifikasi struktur aljabar umum sesuai dengan definisi. Pengujian sifat-sifat umum dan pengujian klasifikasi struktur aljabar umum harus dilakukan terlebih dahulu sebelum pengguna dapat melakukan pengujian untuk klasifikasi bentuk-bentuk struktur matematika khusus (Pevtsova, et al., 2009).

Jika pengujian sifat-sifat umum dan pengujian klasifikasi struktur matematika umum telah membuktikan bahwa sistem aljabar tersebut adalah sebuah grup, maka pengguna dapat melanjutkan instruksi program untuk menguji beberapa bentuk grup khusus, yaitu siklik, berhingga (aperiodik, 
periodik, dan campuran), faktor, subgrup normal, dan homomorfisma. Pada pengujian homomorfisma pengolahan data akan berjalan jika kedua sistem aljabar yang di-input terbukti sebagai grup. Selain itu pada uji homomorfisma juga akan diuji bentuk derivatif homomorfisma, yakni sifat isomorfisma, monomorfisma, dan epimorfisma. Pada pengujian subgrup normal dan grup faktor pengolahan data akan berjalan jika sistem aljabar terbukti merupakan grup serta sistem aljabar lainnya merupakan subgrup dari grup tersebut. Secara garis besar sistem pengujian dimaksud dapat dilihat pada gambar 1 (Shneiderman, 2000).

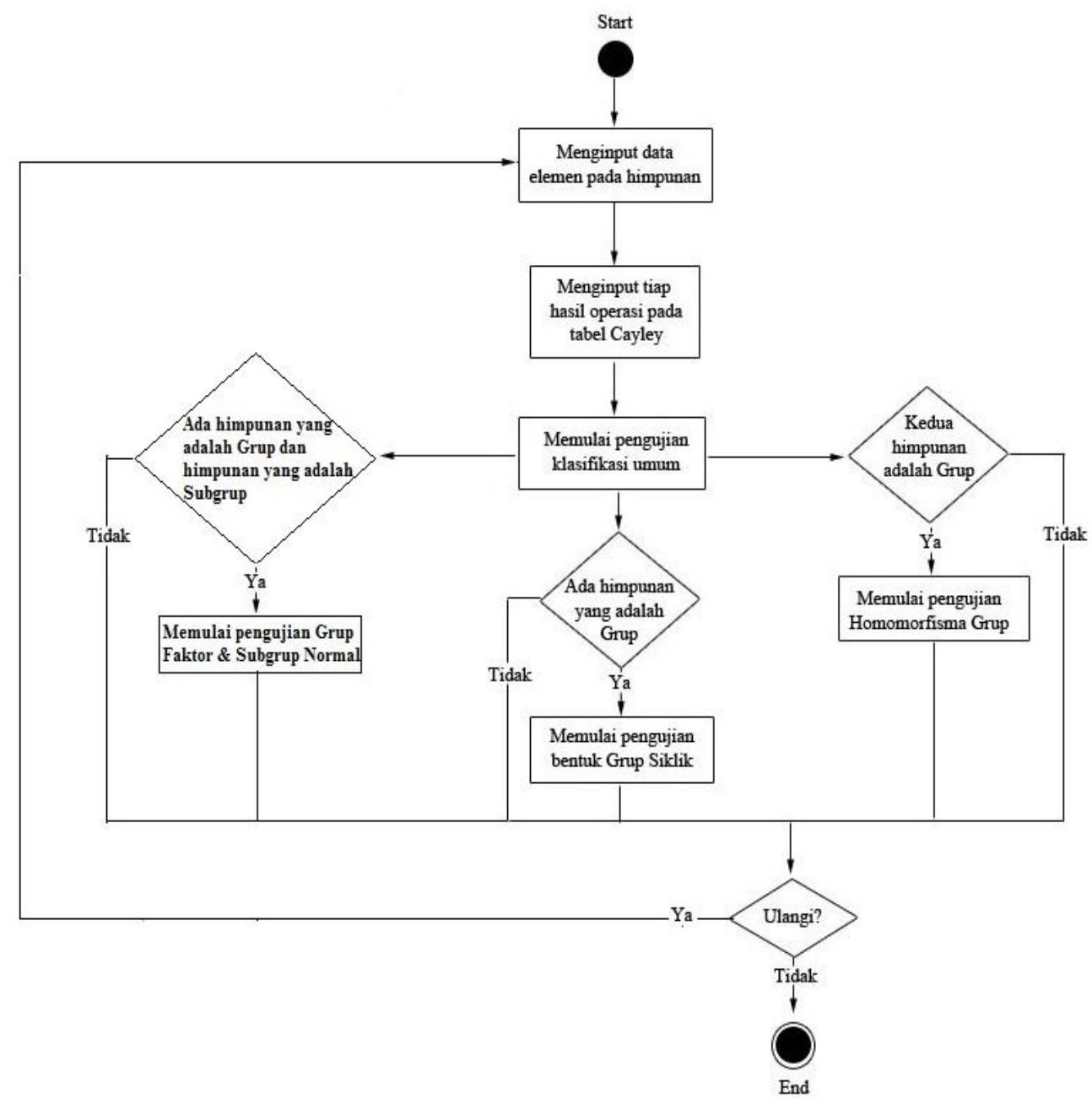

Gambar 1 Flow Chart Sistem Kontrol Modul

\section{HASIL DAN PEMBAHASAN}

Agar program yang telah dikembangkan dapat digunakan, maka ada spesifikasi yang harus dipenuhi yaitu perangkat keras yang digunakan dalam perancangan program adalah sebagai berikut: Processor Intel Pentium Dual-Core CPU T4400 @ 2.20GHz, RAM 953 MB DDR, Hard disk 160 Gbdan Mouse Logitech. Sedangkan spesifikasi dari perangkat lunak yang digunakan dalam perancangan program ini adalah sistem operasi Microsoft Windows XP Professional Service Pack 3, Library Java, dengan meng-install Java ${ }^{\mathrm{TM}}$ Standard Edition Development Kit 6 Update 2. Adapun tampilan layar pembuka untuk piranti lunak dimaksud sebagai berikut terlihat pada gambar 2 . 


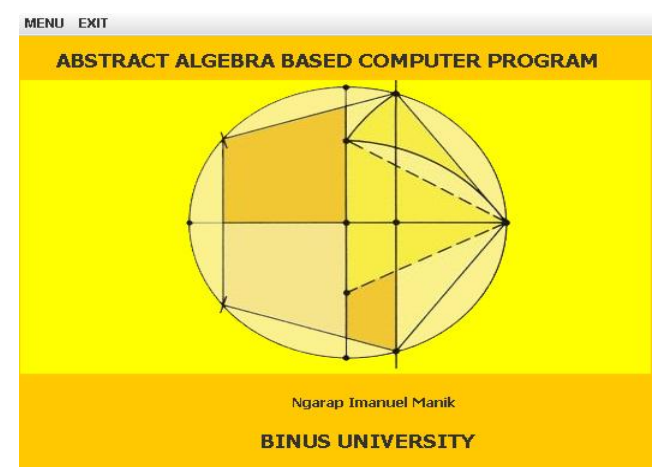

Gambar 2 Tampilan awal Piranti Lunak

Dari layar tersebut jika ingin pengujian tentang Grup atau Ring dapat dilihat dengan mengklik pilihan menu di atas, seperti yang ditampilkan pada gambar 3. (untuk pengujian Ring-Field)

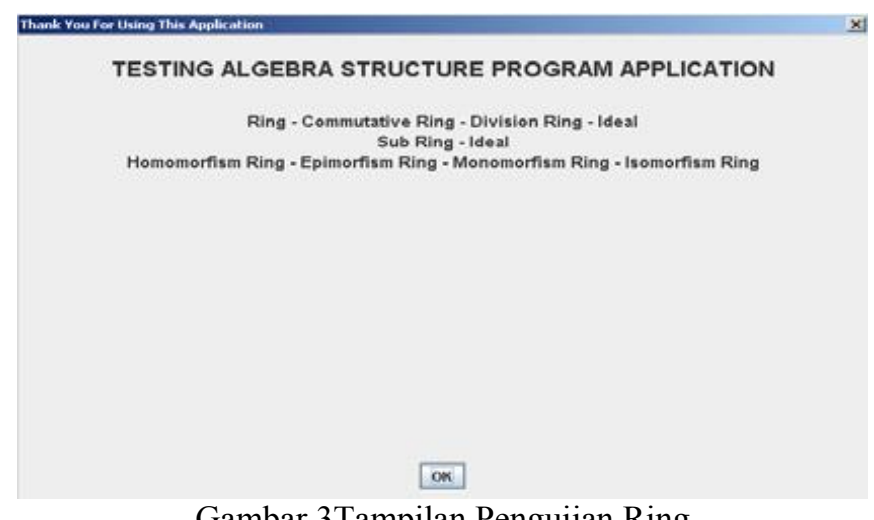

Gambar 3Tampilan Pengujian Ring

Di dalam layar tampilan prolog terdapat judul program, identitas penulis, dan sebuah JButton. JButton ini berguna untuk menutup layar tampilan prolog dan membuka layar tampilan utama. Setelah JButton OK dipilih, akan tampil tampilan menu utama program. Pengguna memiliki 4 pilihan tab menu di sebelah kiri. Masing-masing tab menu memiliki tiga sampai empat sub-tab yang masingmasing memuat tampilan antar muka yang memiliki fungsi masing-masing.

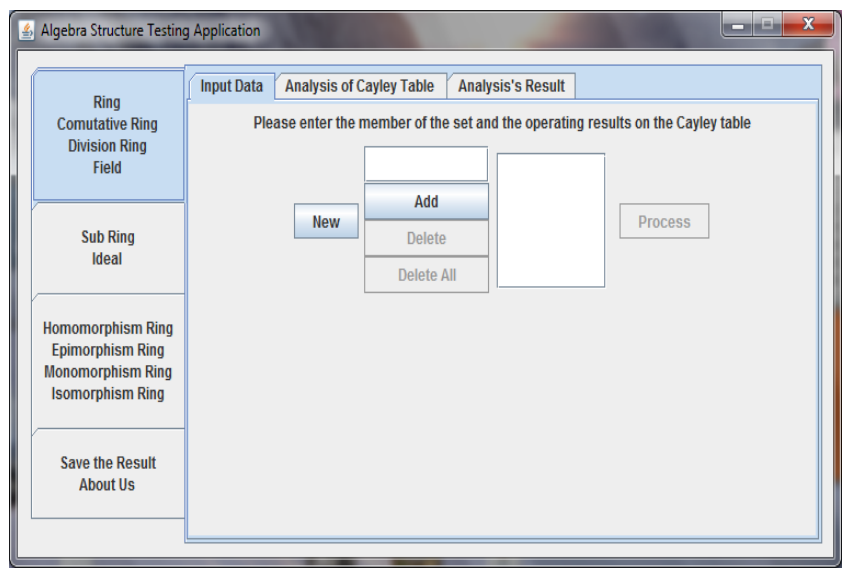

Gambar 4 Tampilan menu pengujian Ring, Commutative Ring, Division Ring dan Field 
Pada gambar 4, terdapat sebuah JTextField yang dapat digunakan pengguna untuk memasukkan elemen dari struktur aljabar yang ingin diuji, JButton "Add" untuk melakukan fungsi menambahkan elemen di JtextField ke dalam JList, JButton "Delete" untuk menghapus elemen, JButton "Delete All" untuk mengosongkan JList, JButton "New" untuk menyediakan form baru bagi proses pengujian, dan JButton "Process" yang menandakan pengguna telah selesai memasukkan elemen struktur aljabar, dan siap untuk mengisi tabel Cayley.

Setelah pengguna selesai memasukkan elemen dengan jumlah minimal dua elemen dalam satu himpunan, pengguna dapat memasukkan isi tabel Cayley. Seperti gambar 5

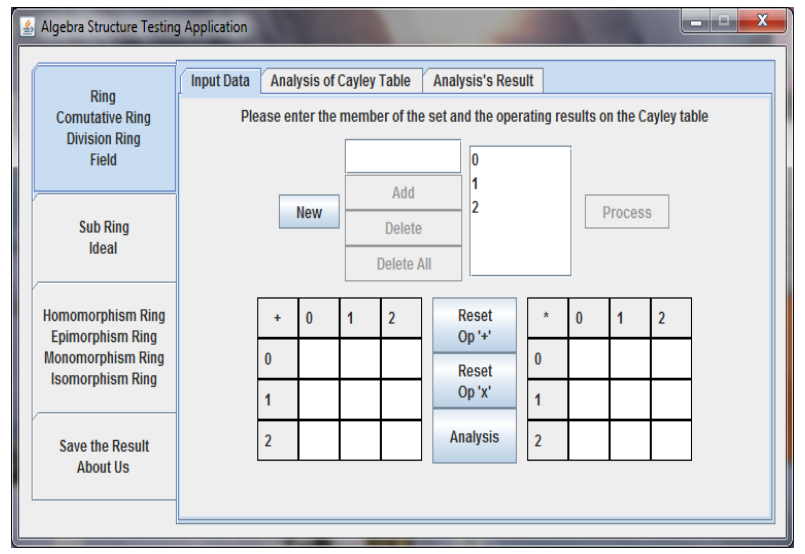

Gambar 5Tampilan pengisian tabel Cayley

Selain hasil pengujian, kesimpulan terhadap hasil pengujian juga telah dapat dilihat pada subtab "Analysis's Result” lihat gambar 6.

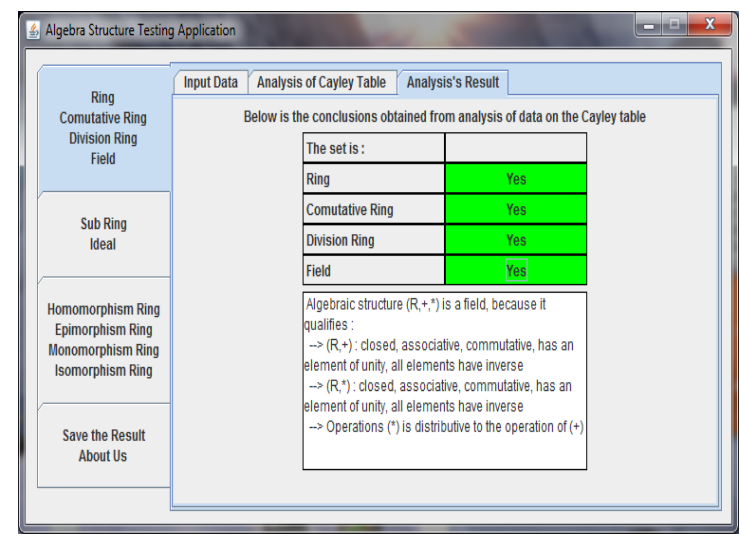

Gambar 6 Tampilan sub-tab "Analysis's Result”

Setelah pengguna selesai memasukkan isi tabel Cayley, pengguna dapat menekan JButton "Analysis". Hasil analisis dari kedua tabel Cayley terdapat pada sub-tab "Testing Result". Seperti kedua tab sebelumnya, pada tab ini pun pengguna dapat mengakses keterangan dari masingmasing kesimpulan dengan menekan tombol yang bersangkutan. Lihat gambar 7 . 


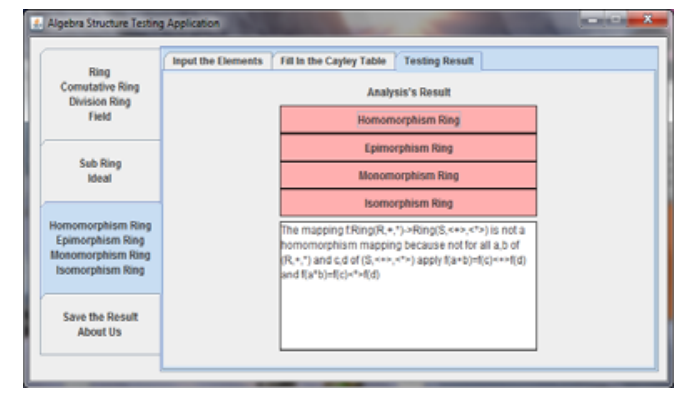

Gambar 7 Tampilan tab Homomorphism

Bagi pengguna yang ingin mencetak hasil pengujian ke kertas, tersedia JButton untuk mengakses operasi penyimpanan hasil pengujian ke file .txt yang dapat dicetak melalui program Notepad. JButton tersebut terdapat pada tab keempat,"Save the Result-About Us"

\section{Pembahasan 1}

Untuk memastikan kemampuan program dalam melakukan pengujian, maka perlu dilakukan pembandingan antara hasil manual dengan output dari program. Akan dilakukan salah satu pengujian dengan menggunakan tabel Cayley tentang Pengujian Ring, Ring Komutatif, Ring Pembagian, Field (Penjumlahan Modulo 4) yang ditampilkan di bawah ini.

Testing Result for: Ring, Commutative Ring, Division Ring, and Field

\section{ANALYSISRESULTFROM CAYLEYTABLE}

1. Closed to the operation of $(+)$

--> For all $a, b$ of $R$, the result of $a+b$ is also a member of $R$

Hasil pengujian diatas menyatakan bahwa berdasarkan tabel Cayley operasi + dan pseudocode memenuhi sifat tertutup terhadap operasi +

2. Elements that generate the left and right sides together:

$0+(0+0)=0<--$ is equal to $-->0=(0+0)+0$

$0+(0+1)=1<-$ is equal to $-->1=(0+0)+1$

$0+(0+2)=2<-$ is equal to $-->2=(0+0)+2$

$0+(0+3)=3<-$ is equal to $-->3=(0+0)+3$

$0+(1+0)=1<--$ is equal to $-->1=(0+1)+0$

$0+(1+1)=2<--$ is equal to $-->2=(0+1)+1$

$0+(1+2)=3<--$ is equal to $-->3=(0+1)+2$

$0+(1+3)=0<--$ is equal to $-->0=(0+1)+3$

$0+(2+0)=2<--$ is equal to $-->2=(0+2)+0$

$0+(2+1)=3<-$ is equal to $-->3=(0+2)+1$

$0+(2+2)=0<--$ is equal to $-->0=(0+2)+2$

$0+(2+3)=1<--$ is equal to $-->1=(0+2)+3$

$0+(3+0)=3<-$ is equal to $-->3=(0+3)+0$

$0+(3+1)=0<-$ is equal to $-->0=(0+3)+1$

$0+(3+2)=1<-$ is equal to $-->1=(0+3)+2$

$0+(3+3)=2<--$ is equal to --> $2=(0+3)+3$

Associative to the operation of $(+)$

--> For all a, b, c of R, apply a $+(b+c)=(a+b)+c$ 
Hasil pengujian diatas menyatakan bahwa berdasarkan tabel Cayley operasi + memenuhi sifat asosiatif terhadap operasi +

3. Comutative to the operation of $(+)$

$-->$ For all a, b of R, apply $a+b=b+a$

Hasil pengujian diatas menyatakan bahwa berdasarkan tabel Cayley operasi + memenuhi sifat komutatif terhdp operasi +

4. Has an element of unity for the operation $(+)$, that is 0

Hasil pengujian diatas menyatakan bahwa berdasarkan tabel Cayley operasi + memiliki unsur kesatuan terhadap operasi +

5. Inverse of each element contained in the operation $(+)$ :

Inverse of 0 is 0 ; Inverse of 1 is 3 ; Inverse of 2 is 2 ; Inverse of 3 is 1

Hasil pengujian diatas menyatakan bahwa berdasarkan tabel Cayley operasi + setiap unsur memiliki invers terhadap operasi +

6. Closed to the operation of $(*)$

--> For all $\mathrm{a}, \mathrm{b}$ of $\mathrm{R}$, the result of $\mathrm{a} * \mathrm{~b}$ is also a member of $\mathrm{R}$

Hasil pengujian diatas menyatakan bahwa berdasarkan tabel Cayley operasi $*$ memenuhi sifat tertutup terhadap operasi $*$

7. Elements that generate the left and right sides together :

$0 *(0 * 0)=0<-$ is equal to -->0 $0=(0 * 0) * 0$

$0 *(0 * 1)=0<-$ is equal to $-->0=(0 * 0) * 1$

$0 *(0 * 2)=0<-$ is equal to $-->0=(0 * 0) * 2$

$0 *(0 * 3)=0<-$ is equal to $-->0=(0 * 0) * 3$

$0 *(1 * 0)=0<-$ is equal to $-->0=(0 * 1) * 0$

$0 *(1 * 1)=0<-$ is equal to $-->0=(0 * 1) * 1$

$0 *(1 * 2)=0<-$ is equal to $-->0=(0 * 1) * 2$

$0 *(1 * 3)=0<-$ is equal to $-->0=(0 * 1) * 3$

$0 *(2 * 0)=0<-$ is equal to $-->0=(0 * 2) * 0$

$0 *(2 * 1)=0<-$ is equal to $-->0=(0 * 2) * 1$

$0 *(2 * 2)=0<-$ is equal to $-->0=(0 * 2) * 2$

$0 *(2 * 3)=0<-$ is equal to $-->0=(0 * 2) * 3$

$0 *(3 * 0)=0<-$ is equal to $-->0=(0 * 3) * 0$

$0 *(3 * 1)=0<-$ is equal to $-->0=(0 * 3) * 1$

$0 *(3 * 2)=0<-$ is equal to $-->0=(0 * 3) * 2$

$0 *(3 * 3)=0<-$ is equal to $-->0=(0 * 3) * 3$

Associative to the operation of $(*)$

--> For all a, b, c of R, apply a* $(\mathrm{b} * \mathrm{c})=(\mathrm{a} * \mathrm{~b}) * \mathrm{c}$

Hasil pengujian diatas menyatakan bahwa berdasarkan tabel Cayley operasi $*$ memenuhi sifat asosiatif terhadap operasi *

8. Comutative to the operation of $(*)$

$-->$ For all a, b of R, apply a* b $=\mathrm{b} * \mathrm{a}$

Hasil pengujian diatas menyatakan bahwa berdasarkan tabel Cayley operasi $*$ memenuhi sifat komutatif terhdp operasi *

9. Has an element of unity for the operation $(*)$, that is 1

Hasil pengujian diatas menyatakan bahwa berdasarkan tabel Cayley operasi * memiliki unsur kesatuan terhadap operasi * 
10. Inverse of each nonzero element contained in the operation $(*)$ :

Inverse of 1 is 1 ; Element 2 has no inverse ; Inverse of 3 is 3

Hasil pengujian diatas menyatakan bahwa berdasarkan tabel Cayley operasi * tidak setiap unsur memiliki invers terhadap operasi *. Elemen 2 tidak memiliki invers karena tdk ada kolom yang mencantumkan unsur kesatuan operasi *, yaitu 1 pd baris 2 .

11. Checking the left distributive :

$0 *(0+0)=0<--$ is equal to $-->0=(0 * 0)+(0 * 0)$

$0 *(0+1)=0<-$ is equal to -- $>0=(0 * 0)+(0 * 1)$

$0 *(0+2)=0<-$ is equal to $-->0=(0 * 0)+(0 * 2)$

$0 *(0+3)=0<-$ is equal to -->0 $0=(0 * 0)+(0 * 3)$

$0 *(1+0)=0<-$ is equal to $-->0=(0 * 1)+(0 * 0)$

$0 *(1+1)=0<-$ is equal to $-->0=(0 * 1)+(0 * 1)$

$0 *(1+2)=0<-$ is equal to $-->0=(0 * 1)+(0 * 2)$

$0 *(1+3)=0<-$ is equal to -->0 $=(0 * 1)+(0 * 3)$

$\sim$ LEFT DISTRIBUTIVE FULFILLED

Checking the right distributive :

$(0+0) * 0=0<-$ is equal to -- $>0=(0 * 0)+(0 * 0)$

$(0+0) * 1=0<-$ is equal to -->0 $0=(0 * 1)+(0 * 1)$

$(0+0) * 2=0<-$ is equal to $->0=(0 * 2)+(0 * 2)$

$(0+0) * 3=0<-$ is equal to -->0 $=(0 * 3)+(0 * 3)$

$(0+1) * 0=0<-$ is equal to $-->0=(0 * 0)+(1 * 0)$

$(0+1) * 1=1<--$ is equal to $-->1=(0 * 1)+(1 * 1)$

$(0+1) * 2=2<-$ is equal to $-->2=(0 * 2)+(1 * 2)$

$(0+1) * 3=3<-$ is equal to --> $3=(0 * 3)+(1 * 3)$

\section{$\sim \sim$ RIGHT DISTRIBUTIVE FULFILLED}

All the elements satisfy the distributive properties of operations $\left(^{*}\right)$ on the operations of $(+)$ as the fulfillment of left distributive and right distributive

Hasil pengujian diatas menyatakan bahwa berdasarkan tabel Cayley operasi + dan tabel Cayley operasi *, memenuhi sifat distributive operasi * terhadap operasi +

\section{CONCLUSION}

With members : $0,1,2,3$

Algebraic structure $(\mathrm{R},+, *)$ is a ring, because it qualifies :

$-->(R,+)$ :closed, associative, commutative, has an element of unity, all elements have inverse

$-->\left(\mathrm{R},{ }^{*}\right)$ : closed, associative

--> Operations $\left({ }^{*}\right)$ is distributive to the operation of $(+)$

Hasil pengujian diatas menyatakan bahwa berdasarkan hasil pengujian merupakan sebuah ring

Algebraic structure $\left(\mathrm{R},+{ }^{*}\right)$ is a commutative ring, because it qualifies :

--> $(\mathrm{R},+)$ : closed, associative, commutative, has an element of unity, all elements have inverse

$-->\left(\mathrm{R},{ }^{*}\right)$ : closed, associative, commutative

--> Operations $(*)$ is distributive to the operation of $(+)$

Hasil pengujian diatas menyatakan bahwa berdasarkan hasil pengujian merupakan sebuah ring komutatif

Algebraic structure $(\mathrm{R},+, *)$ is not a division ring, because not every element has an inverse in operation $(*)$ 
Hasil pengujian diatas menyatakan bahwa berdasarkan hasil pengujian bukan merupakan sebuah ring pembagian

Algebraic structure $\left(\mathrm{R},+,{ }^{*}\right)$ is not a field, because not every element has an inverse in operation $(*)$

Hasil pengujian diatas menyatakan bahwa berdasarkan hasil pengujian bukan merupakan sebuah field

\section{Pembahasan 2.}

Sedangkan untuk pengujian Grup dapat diberikan dengan contoh percobaan pada 2 himpunan berbeda, yaitu :

Sistem Aljabar $\left(\mathrm{G},{ }^{*}\right)$ terdiri dari:

Himpunan $\mathrm{G}=\{0,1,2\}$

Operasi “*” didefinisikan sebagai operasi penjumlahan modulo 3

Sistem Aljabar $(\mathrm{H}, \#)$ terdiri dari:

Himpunan permutasi $\mathrm{H}=\left\{\left(\begin{array}{l}1 \\ 1\end{array}\right),\left(\begin{array}{lll}1 & 2 & 3\end{array}\right),\left(\begin{array}{lll}1 & 3 & 2\end{array}\right),\left(\begin{array}{ll}1 & 2\end{array}\right),\left(\begin{array}{ll}1 & 3\end{array}\right),\left(\begin{array}{ll}2 & 3\end{array}\right)\right\}$

Operasi “\#” didefinisikan sebagai operasi komposisi

Seperti contoh sistem aljabar di atas, sekarang akan diproses dengan menggunakan program aplikasi pengujian yang telah dikembangan untuk melihat apakah program aplikasi dapat memberikan hasil yang tepat, sesuai dengan pengujian secara manual. Pertama-tama, perlu di-input elemen dari masing-masing sistem aljabar, seperti berikut.

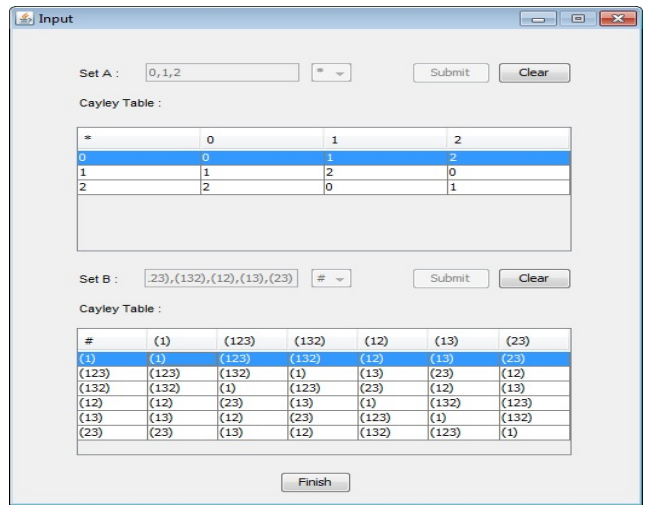

Gambar 8 Input Elemen Masing Himpunan

Setelah tiap elemen hasil operasi selesai di-input, tombol Finish perlu ditekan. Kemudian program akan menuju pada tampilan selanjutnya. Berikut adalah beberapa tampilan hasil pengujian himpunan A dan himpunan B terhadap grup khusus.

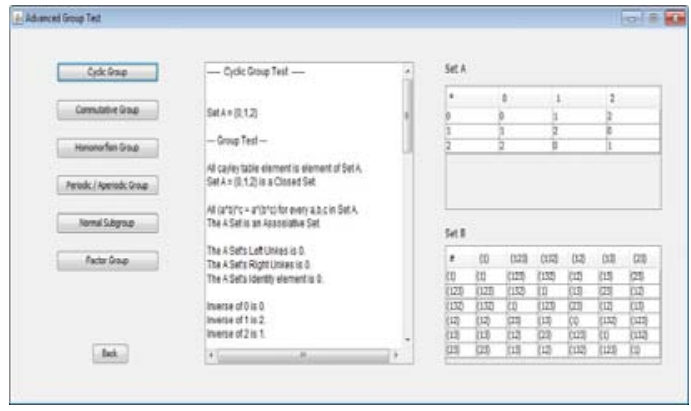

Gambar 9 Hasil Uji Grup Siklik 


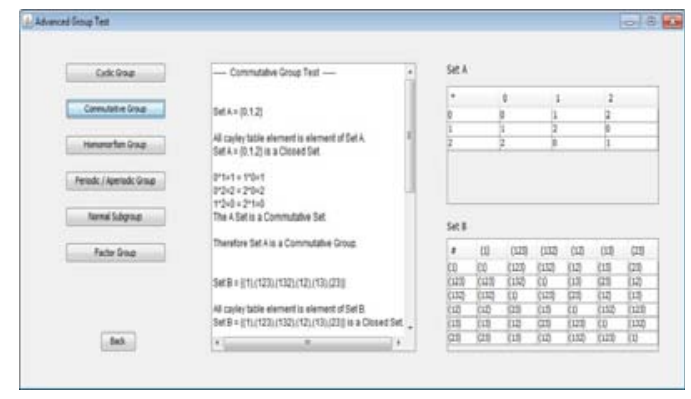

Gambar 10 Hasil Uji Grup Komutatif

Dengan melihat perbandingan hasil antara pengujian secara manual dengan pengujian melalui program aplikasi, dapat dilihat bahwa program aplikasi dapat memberikan hasil pengujian yang tepat, sama dengan pengujian secara manual.

\section{SIMPULAN}

Piranti lunak aplikasi pengujian Grup, Ring \& Field ini dapat beroperasi dengan baik, memberikan hasil yang sama dengan pengujian manual, namun dengan waktu yang lebih singkat dan serta ketelitian yang lebih tinggi karena dikerjakan oleh komputer. Piranti lunak ini dapat melakukan pengujian Grup Siklik, Grup Isomorphisma, Semi Grup, Sub Grup dan Grup Abelian, ring, ring komutatif, ring pembagian field, sub-ring, ideal, homomorfisma ring, epimorfisma ring, monomorfisma ring dan isomorfisma ring Piranti lunak ini dapat digunakan sebagai alat bantu pengujian struktur matematika menjadi lebih efektif, efisien. Keakuratan hasil pengujian tergantung pada ketelitian memasukkan isi dari tabel Cayley.

\section{DAFTAR PUSTAKA}

Arifin, D. (2011). Perancangan PengembanganProgram Aplikasi Pengujian Struktur Aljabar Ring, Ring Komutatif, Field, Sub Ring, Ideal. Thesis Collection for S-1, diakses dari http://library.binus.ac.id/

Bergstra, J.A., Tucker, J.V. (2008). Division Safe Calculation in Totalised Fields. Theory Computer System, 43(01), 410-424

Carlson, D. (2003). The Teaching and Learning of Tertiary Algebra. Prosiding Seminar Nasional Aljabar dan Pengajaran Aljabar di Perguruan Tinggi.

Dewi, N.R., et al. (2011). Kajian Struktur Aljabar Grup pada Himpunan Matriks yang Invertibel. Jurnal Penelitian Sains, 14(1A), 14101-1 sampai 14101-3

Gilbert, W.J., Nicholson, W.K. (2004). Modern Algebra with Application. (2ed). USA

Manik, N.I. Pengujian Struktur Aljabar Grup, Ring, \& Field Berbasis Komputer. Prosiding SNM2010. Universitas Indonesia, Jakarta.

Malik, D.S., et al. (2007). Introduction to Abstract Algebra, diakses dari https://people.creighton.edu/ 
Okur, M. (2006). Computer Applications in Teaching Abstract Algebra, International Journal of Applied Science and Technology, 1(1), 20-27

Pevtsova, et al. (2009). Varieties for Modules of Quantum Elementary Abelian Groups.Algebras and Representation Theory, 12(2-5), 74-86

Shneiderman, B. (2000), Designing the User Interface - Strategies for Effective Human-Computer Interaction. (Fourth Edition) USA: Addison-Wesley.

Weisstein, et al. (2009). Noncommutative Rings and Geometry. Algebras and Representation Theory, 12(2-5), $15-25$ 